\title{
Enska sem kennslumál við Háskóla Íslands og kennsla í akademískri ensku
}

\section{Inngangur}

Totkun á ensku hefur aukist mög í háskólastarfi í löndum par 1 sem enska er alla jafna skilgreind sem erlent ${ }^{1}$ mál (e. English as a foreign language, (EFL)). Í nýlegri skýrslu sem gefin var út af British Council kemur fram að merkja megi pessa próun um allan heim en að skiptin úr heimamálinu yfir í ensku sem kennslumál séu hvað hröðust í háskólum á Norðurlöndum sem vilja styrkja alpjóðlega stöðu sína (Dearden, 2015; Wächter og Maiworm, 2015). Ísland hefur ekki farið varhluta af pessum breytingum (Birna Arnbjörnsdóttir og Hafdís Ingvarsdóttir, 2018) en lokaritgerðum sem ritaðar eru á ensku fer hér fjölgandi og sífellt fleiri námskeið á háskólastigi eru kennd á ensku. Í rannsókn frá 2009 kom í ljós að yfir 90\% námsbóka sem notaðar eru við íslenska háskóla eru ritaðar á ensku (Birna Arnbjörnsdóttir, 2009).

Á sama tíma og kennsla á ensku fer vaxandi við norræna háskóla hefur stöðugt meiri athygli verið vakin á peim vandkvæðum sem fylgja pví að nemendum og kennurum sé gert að læra og kenna á sérhæfðu erlendu tungumáli sem peir hafa ekki á valdi sínu, enda ljóst að á Norðurlöndum er móðurmálið (e. first language) skólamál flestra nemenda á fyrri skólastigum (Hultgren o.fl., 2014). Fjölmargar rannsóknir í pessum löndum benda til pess að margir, bæði nem-

1 Hér er átt við mál sem er alla jafna hvorki móðurmál né annað mál. 
endur og kennarar, eigi í vandræðum með að nota ensku í háskólastarfi (Dimova o.fl., 2015; Pecorari o.fl., 2011; Malmström o.fl., 2016; Paulsrud, 2014). Rannsóknir á Íslandi styðja pessar niðurstöður og sýna að yfir 60\% háskólanema eiga í erfiðleikum með að skilja og nota ensku og að margir purfa að leggja á sig mikla aukavinnu til að ná tökum á námsefni á ensku. Pá á um priðjungur nemenda í verulegum vandræðum með að skilja fræðilegan texta og skrifa á ensku prátt fyrir allt að tíu ára enskunám (Birna Arnbjörnsdóttir og Hafdís Ingvarsdóttir, 2015, 2018).

Vandkvæði nemenda má t.d. skýra með misræmi í námsmarkmiðum milli skólastiga, sem gerir pað að verkum að margir norrænir nemendur koma ekki nægilega vel undirbúnir af fyrri námsstigum til að takast á við fræðilegt háskólanám á ensku (Hellekjær, 2005, 2009; Birna Arnbjörnsdóttir og Gerður Guðmundsdóttir, 2014). Rannsóknir Guðmundar Edgarssonar (2018) sýndu t.d. að íslenskir nemendur höfðu ekki pann orðaforða og lesskilning á ensku sem krafist er í hefðbundnum færniprófum við inntöku í háskóla í enskumælandi löndum. Gerður Guðmundsdóttir og Birna Arnbjörnsdóttir (2014) hafa einnig bent á að við̀mið á efri stigum enskukennslu í gildandi námskrá í erlendum tungumálum fyrir framhaldsskóla séu ekki skýr og ekki einsýnt að framför verði milli enskuáfanga á efstu stigum. Pá er ljóst að hefðbundin bókmenntamiðuð kennsla í ensku í íslenskum framhaldsskólum nýtist ekki öllum nemendum pegar í háskóla er komið (Anna Jeeves, 2013; Birna Arnbjörnsdóttir \& Prinz, 2017; Hafdís Ingvarsdóttir, 2018). Einnig virðist sem norrænir, og par með íslenskir, nemendur og kennarar ofmeti almennt enskukunnáttu sína með peim afleiðingum að ekki er gert ráð fyrir að nemendur purfi stuðning við enskunotkun í háskólastarfi (Hellekjær, 2009; Birna Arnbjörnsdóttir og Hafdís Ingvarsdóttir, 2018). Við petta bætist skortur á námsefni og kennsluaðferðum sem mæta pörfum nemenda sem nota ensku í háskólanámi (Dearden, 2015, bls. 22-23). Af pessu má vera ljóst að brýn pörf er á pví að próuð verði skilvirk leið til að styðja við nemendur í námi sem fram fer á ensku (Gardner og Nesi, 2013; Dearden, 2015; Doolan, 2017).

Í pessari grein verður lýst viðbrögðum námsbrautar í ensku við Mála- og menningardeild Háskóla Íslands við sívaxandi fjölda nem- 
enda sem parfnast aðstoðar í akademískri ensku í háskólanámi. Um er að ræða BA-nemendur í ensku sem telja sig vel búna undir pað að takast á við nám í enskum málvísindum og bókmenntum en eiga svo í verulegum vandræðum með fræðilegan lestur og ritun. Petta á pó enn frekar við um pá fjölmörgu nemendur úr öðrum deildum og sviðum Háskólans sem skrá sig í námskeið í enskri ritun til pess að auka akademíska enskufærni sína og auðvelda sér nám á ensku í sínum greinum. Námskeið í ritun í bókmenntum og málvísindum eru ekki líkleg til að auka færni í verkfræði- eða lagaensku svo dæmi séu tekin. Fjölgun nemenda með pessar ólíku parfir leiddi til mikils álags á kennara í greininni sem nú purftu að mæta pörfum fjölda nemenda með mismunandi færni og markmið í námskeiðum, par sem engin sérstök námskeið í akademískri ensku fyrir nemendur með aðrar parfir voru í boði í námsbrautinni eins og tỉokast við námsbrautir í ensku við háskóla í enskumælandi löndum. Fjölmenn, lítt eða ekki sérhæfð námskeið af pessu tagi leiddu til almennrar óánægju meðal nemenda jafnt sem kennara og höfðu í för með sér tî̉ kennaraskipti. Námsefnið hæfði ekki nemendum og framfarir í ritun voru óásættanlegar.

Námsbraut í ensku brást við peim vanda sem hér hefur verið lýst með tvennum hætti; annars vegar með pví að setja á fót sérstakt diplómanám í akademískri ensku fyrir nemendur úr öðrum fræðigreinum sem vilja bæta enskufærni sína og hins vegar með pví að laga ritunarkennslu í BA-námi í ensku að ritunarhefðum í enskum bókmenntum í einu námskeiði og ritunarhefðum í málvísindum í öðru. Strax varð pó ljóst að flesta nemendur, bæði í BA-námi í ensku og akademískri ensku, skorti undirstöðu í fræðilegri ritun á ensku sem byggist á framsetningu tilgátu (e. thesis statement) í inngangi og stýrir uppbyggingu textans (Hyland, 2017). Parfagreiningar bentu til pess að pótt nemendur pekktu hugtökin 'thesis', 'evidence', 'introduction' og 'conlusion' áttu peir erfitt með yfirfæra pessa pekkingu í ritun (Birna Arnbjörnsdóttir og Prinz, 2017). Nauðsynlegt reyndist pví að pjálfa nemendur í grunnatriðum akademískrar ritunar á ensku áður en hægt var að hefja kennslu í ritun sérhæfðra texta. Aðferðin miðaðist að pví að byggja ofan á hæfni nemenda í ensku talmáli, sérstaklega skilningi, og tiltölulega góðri undirstöðu í málfræðilega réttu máli (e. accuracy). 
Nálgunin sem próuð var byggði ofan á kunnáttu nemenda í ensku talmáli og leiddi pá smám saman að sjálfstæðum vinnubrögðum í fræðilegri ritun sem stýrt var af tilgátu (e. thesis driven writing). Undirstöðupjálfun í akademískri ensku við námsbrautina byggist á greiningu og ritun mismunandi textategunda (e. genre-based writing), par sem áhersla er lögð á pjálfun í ritun texta sem einkennir viðkomandi fræðasvið. Markmiðið með pessari aðferð var að hjálpa nemendum að átta sig á uppbyggingu texta innan sinnar fræðigreinar og auka með pví lesfærni peirra (e. discipline based/genre-based teaching) (Swales, 2004; Tribble og Wingate, 2013; Hyland, 2017). Nálgunin sem hér var byggt á er sett fram í bókinni The Art and Architecture of Academic Writing (Prinz \& Arnbjörnsdóttir, 2020) en í pessari grein verður ýmist vísað í nálgunina og pær aðferðir sem henni fylgja eða námsbókina sjálfa.

Nálgunin hefur verið í stöðugri próun um sjö ára skeið og fyrir liggur mikill fjöldi gagna sem mæla árangur hennar. Par á meðal eru kennslukannanir, spurningakannanir við upphaf og lok námskeiðs, ritunarverkefni fyrir og eftir kennslu, hugleiðingar og viðtöl við kennara og nemendur. Í pessari grein verður fyrst lýst fræðilegum undirstöðum nálgunarinnar, pá verður nálguninni sjálfri lýst og síðan gerð stutt grein fyrir niðurstöðum rannsókna á áhrifum hennar á nám nemenda, p.e. hvernig peir upplifa framfarir sínar í akademískri ritun á ensku sem er stýrt af tilgátu og hvort peir telji sig hafa próað með sér sjálfstæði í vinnubrögðum (e. autonomy) sem peir geti nýtt sér í námi sínu (Arnbjörnsdóttir og Prinz, 2017; Arnbjörnsdóttir og Prinz, 2020). Að lokum verður greint frá rannsókn á mælanlegum framförum í enskri ritun eins og pær birtust í skrifum nemenda í byrjun og lok námskeiðsins.

\section{The Art and Architecture of Academic Writing: Fræðilegur bakgrunnur}

Nútíma ritunarkennsla byggist á peirri hugmyndafræði að ritunarhefðir séu bundnar við faggreinar og innan hverrar peirra hafi próast fastar, óskrifaðar reglur um uppbygginu texta og orðræðu. Pessar kenningar má rekja til hugmynda Lave og Wengers (1991) um sam- 
félög málhefða (e. communities of practice). Í kjölfarið varð til nálgun sem byggð er á pví að áhrifaríkasta leiðin til að kenna ritun sé að kenna og pjálfa nema í að skrifa texta sem grundvallast á hefðum fræðasviðs peirra. Með öðrum orðum er byggt á peirri hugmynd að hver textagerð hafi sitt snið p.e. hugmyndinni um mismunandi textategundir (e. genre based writing) (Swales, 2004; Hyland, 2017) sem pá parf að hafa í huga við ritun. Kenningin gundvallast m.a. á pví að textar og málnotkun t.d. í verkfræði séu öđruvísi en textar í málvísindum og að textar í bókmenntum séu öđruvísi en í blaðagreinum. Ritunarkennsla eigi að hafa pað að markmiði að pjálfa nema í skrifum sem lúta lögmálum hvers fræðasviðs. Skilvirkast sé að kenna nemendum að skrifa pá tegund texta sem einkennir námsbækur peirra og kennarar peirra vænta af peim. Pessi aðferðafræði við ritunarkennslu tekur pannig mið af pörfum nemandans með minni áherslu á sjálft ritunarferlið (e. process writing), eins og áđur tíðkaðist, eða á lokaafurðina, ritgerðina sjálfa, sem oftast er metin út frá pví hvort almennum lokamarkmiðum hafi verið náð án pess að nemendum sé sýnt hvernig peir eigi að ná settum markmiðum í skrifum sínum. Sú aðferð að byggja kennsluna á mismunandi textategundum hefur reynst vel og er jafnframt sú sem mest er fjallað um í fræðilegri umræðu um ritunarkennslu, bæði fyrir nemendur með ensku að móðurmáli (e. English as a native language, ENL) og nemendur sem eru að læra ensku (e. English as a second language, ESL). Hún hefur reynst sérstaklega vel fyrir nemendur eins og íslenska háskólanema sem eru menntaðir á íslensku, skilja ensku en purfa að stunda háskólanám á fræðilegri ensku (e. English as a medium of instruction (EMI)).

Aðferðin hefur hins vegar reynst erfið í framkvæmd; hún er kostnaðarsöm og krefst sérhæfingar í viðkomandi grein auk pekkingar á tungumálinu. Kostnaðurinn við að setja upp námskeið í enskri ritun innan allra fræðigreina er mikill og erfitt að manna slík námskeið en erfiðast er pó að réttlæta hvers vegna námskeið í sérgrein nemenda ættu að víkja fyrir námskeiði í ritun á ensku. Ofmat nemenda, kennara og yfirstjórna háskóla á eigin enskukunnáttu er líka ein ástæðan fyrir tregðunni. Pað kunna jú allir ensku og námsgreinabundin/fagtengd kennsla í ensku pví ópörf. Petta á jafnt við um Háskóla Íslands sem aðra háskóla par sem fjöldi viðtala við nemendur og kennara hafa leitt í ljós að prátt fyrir yfirlýsta ánægju með undir- 
búning í ensku hafi hann samt sem áđur ekki reynst nægilegur til að mæta pörfum peirra í námi og starfi (Hafdís Ingvarsdóttir og Birna Arnbjörnsdóttir, 2013; Birna Arnbjörnsdóttir og Hafdís Ingvarsdóttir, 2015, 2018). Afleiðing pessa var sú að nemendum úr öðrum deildum Háskólans fjölgaði mjög í ritunarnámskeiðum í BA-námi í ensku.

\section{Viðbrögð námsbrautar í ensku við breyttu málumhverfi}

Innan námsbrautar í ensku hefur ekki reynst mögulegt að bjóða upp á ritunarnámskeið á hverju sérsviði fyrir sig, en próað hefur verið námskeið par sem tekin eru fyrir atriði sem talið er að flestar textategundir eigi sameiginleg og byggjast á premur algengustu tegundum texta sem notaðar eru í háskólanámi. Hugmyndin er byggð á rannsóknum Gardner og Nesi (2012) á peim grunnpáttum sem einkenna texta í risastórum gagnabanka af ritunarverkefnum á háskólastigi. Af pessum textategundum voru prjár langmest áberandi, p.e. esseyjur (e. essays), tilviksskýrslur (e. case studies) og rannsóknarritgerðir (e. research papers). Niðurstöður Gardner og Nesi styðja kenningar um sérstök einkenni hverrar bessara tegunda en undirstrika jafnframt sameiginleg einkenni ritunarverkefna pvert á fræðasvið. Pessi sameiginlegu einkenni eru undirstaða nýrrar nálgunar í kennslu í fræðilegum skrifum við námsbraut í ensku. Nálgunin er hugsuð sem undirbúningur undir lestur og ritun á fræðasviði hvers og eins. Nálgunin byggist pví á verkefnum sem flestir nemendur eru líklegir til að fást við í námi, p.e. esseyjum, sem pjálfar pá í mismunandi framsetningu texta pvert á fræðigreinar; tilviksskýrslum, sem byggðar eru á eigin rannsóknum nemenda; og rannsóknarritgerðum, sem grundvallast á eigin rannsóknum og rannsóknum annarra.

Meginreglan sem gengið er út frá er sú að nemendur fái pjálfun í að̀ setja saman raunhæfar tilgátur (e. thesis) sem sídan stýra uppbyggingu textans, p.e. að innihaldið styðji tilgátuna sem sett er fram og að peir öðlist nægilega pjálfun í pessum undirstöðum til að geta unnið sjálfstæett að námskeiðinu loknu. Áhersla er lögð á að próa færni í einum pætti í einu en peir eru sídan sameinaðir í stærri og 
flóknari verkefni. Pannig eru nemendur til dæmis pjálfaðir í að átta sig á tilgangi efnisgreina og hvers konar rökstuðningur styður tilgátu peirra. Tilgangur inngangs og niðurlags er kenndur sérstaklega. Nemendur sameina sîđan smám saman inngang, efnisgreinar og niðurlag í heila ritgerð og fá æfingu í að skrifa sífellt flóknari texta.

Í námskeiðinu er byrjað á pví að æfa nemendur í grunnatriðum með pví að láta pá skrifa texta sem peir pekkja, s.s. frásögn eða lýsingu. Áhersla í upphafi er lögð á að fá pá til að tjá sig á formlegu ritmáli án pess að purfa að byggja skrifin á heimildum, p.e. finna sína eigin rödd (e. authorial voice). Sỉðan vinna peir verkefni eða skýrslu sem byggð er á eigin rannsóknum án pess að styðjast við heimildir frá öðrum, fá pjálfun í rannsóknaraðferðum og skilning á pví hvernig koma á eigin pekkingu og niðurstöðum á framfæri. Verkefnið býr nemendur undir að leysa verkefni sem peir munu sîđar glíma við (e. case based learning (CBL)) í sínum námsgreinum (Hall o.fl. 2016). Gerð er krafa um að peir geri frumrannsóknir, skipuleggi og greini upplýsingar og skrifi skýrslu. Pannig próa peir með sér dýpri vitneskju um ritun, pjálfa færni í að nota beinar tilvitnanir og endurrita orð viðmælenda sinna (e. paraphrase). Að lokum er efniviður úr skýrslunni settur í félagslegt samhengi með vísun í sérfræðinga. Nemendur hafa par með fengið pjálfun í ritun sem grundvölluð er á peirra eigin skoðunum, frumrannsóknum og mati og vali á heimildum sem styðja við hugmyndir peirra.

Með pessari nálgun er áhersla lögð á að nemendur temji sér sjálfstæði í vinnubrögðum en parfagreining hafði leitt í ljós að prátt fyrir allt að tíu ára nám í ensku beittu nemendur ekki pekkingu sinni á hugtökum í rituninni sjálfri. Markmiðið var pví að breyta pekkingu nemenda á ritun í ritunarfærni, auka sjálfstæði peirra í vinnubrögðum og pjálfa pá í að taka stjórnina í eigin námsferli með pví að umbreyta pekkingu í verkefnatengda hegðun (Zimmerman, 2013; Holec, 1981). Petta er gert með pví að kenna nemendum námsaðferðir sem eiga við á hverju stigi ritunar - frá undirbúningi fyrir ritun og próun tilgátu til kerfisbundinnar endurritunar og prófarkalesturs (Patricia Prinz og Birna Arnbjörnsdóttir, 2020). Notast er við stoðir (e. scaffolding), skýr fyrirmæli og dæmi jafnframt pví sem lestextum er haldið í lágmarki til að auka vægi ritæfinga. 
Nánast hverjum kafla î The Art and Architecture of Academic Writing (Prinz \& Arnbjörnsdóttir, 2020) er skipt upp í pætti eftir verklagi. Í fyrsta pætti er fjallað um vitund og skilning nemandans (e. awareness) á efninu og framsetningu pess og síoan um hvernig skrifa eigi drög að texta (e. writing) og meta pau út frá tilgátu ritgerðar og stuðningi við hana (e. assessment). Par á eftir er fjallað um endurritun draganna út frá matinu (e. revision) og endað á umfjöllun um prófarkalestur (e. editing). Innan hvers páttar eru verkefni sem ætlað er að efla sjálfstæði nemenda í vinnubrögðum, s.s. hugleiðingar (e. reflection), p.e. ígrundun á eigin venjum og námsaðferðum við ritun; tilgangur (e. relevance), nemendur skoða tilgang kennslunnar eða verkefnisins og tengsl við parfir peirra og væntingar fræðasamfélagsins; og æfingar (e. practice), par sem nemendur pjálfa einstaka pætti ritunar áður en peir skrifa fyrstu drög (e. production).

\section{Fyrri rannsóknir á nýrri nálgun í kennslu}

Rannsóknin sem hér er til sérstakrar umfjöllunar er hluti af viðameiri langtímarannsókn á kennslufræðinni sem beitt er í The Art and Architecture of Academic Writing (Prinz \& Arnbjörnsdóttir, 2020). Pátttakendur eru fyrsta árs grunnnemar sem skráđir eru í ritpjálfunarnámskeið í námsbraut í ensku við Háskóla Íslands. Námið er ætlað BA-nemum í ensku og gerð er krafa um enskufærni að prepi C1 á evrópska staðlinum. Fram til 2016 voru flestir nemenda íslenskir en líka alpjóðlegir námsmenn úr ýmsum greinum, nemendur með annan málbakgrunn. Sífellt fleiri nemendur úr öðrum deildum Háskólans, sem ekki höfðu færni upp á C1, skráou sig í námskeiðin með afleiðingum sem áđur er lýst.

Sama könnunin var lögð fyrir við upphaf námskeiðs og í lok pess. Bakgrunnsspurningar leiddu í ljós að í gegnum árin höfðu $90 \%$ svarenda hafið enskunám fyrir 12 ára aldur og næstum helmingur lært ensku í 8-12 ár. Forkannanir sýndu einnig að nemendur voru ánægðir með undirbúning sinn í ensku, en næstum 90\% peirra sögðust hafa góða eða mjög góða færni í skilningi og lestri en heldur færri töldu sig hafa góðan skilning á tali og ritun. Petta er ofmat eins og fyrri rannsóknir hafa sýnt (Birna Arnbjörnsdóttir og Patricia Prinz, 2017; Birna Arnbjörnsdóttir og Hafdís Ingvarsdóttir, 2018). 
Áður hafa birst tvær greinar um hina nýju kennslunálgun. Í peim var sjónum beint að tveimur páttum ritunar: 1 . Hvort nemendur teldu sig í lok námskeiðs geta skrifað texta sem stýrt er af tilgátu; og 2. hvort peir teldu sig vera sjálfstæðari í vinnubrögðum eftir námskeiðið. Greiningin var byggðá gögnum sem safnað var vorið 2013 við upphaf og lok kennslu (Birna Arnbjörnsdóttir og Patricia Prinz, 2017). Pátttakendur í könnuninni sem svöruðu bæði forkönnun og könnun í lok námskeiðs voru 91 eða nánast allir peir nemendur sem luku námskeiðinu. Spurðir um framfarir almennt sögðust 10-12\% vera betri í ritun og einnig í lestri á ensku eftir námskeiðið. Peim sem töldu sig geta skrifað ritgerðir án leiðbeiningar fjölgaði um 13\% og peim sem töldu sig skilja uppbyggingu rannsóknaritgerða um $24 \%$. Mestu breytingarnar milli kannana við upphaf og lok námskeiðs voru samdráttur í fjölda peirra sem merktu við að peir væru hvorki sampykkir né ósampykkir fullyrðingum um ritunarfærni sína og er pað vísbending um að eftir námskeiðið hafi nemendur áttað sig betur á eigin færni og kunnáttu til að skrifa akademíska ensku, sem er áfangi að sjálfstæði í vinnubrögðum (Lavelle og Züercher, 2001).

Á sama misseri, vorið 2013, skiluðu heldur fleiri eða 111 nemendur skriflegum svörum við einni af sex hugleiðingum um ritun sem hluta af námsmati í námskeiðinu. Nemendur voru beðnir um að skila hugleiðingum sínum um framvindu í námskeiðinu og hvernig peim hefði gengið að tileinka sér pær námsaðferðir og námsefni sem fyrir pá var lagt. Hugleiðingin fjallaði um hvernig peim gengi að tileinka sér ritun texta sem stýrt væri af tilgátu, sem er eitt aðaleinkenni akademískra texta á ensku. Beðið var um að peir veltu pessu fyrir sér pegar peir byrjuðu að skrifa ritgerð án pess að vera búnir að ákveða um hvað ritgerðin ætti að fjalla. Greining leiddi í ljós prjú pemu: Fyrsta pemað var skilningur á uppbyggingu akademískra texta en tveir priðju nemendanna lýstu pví hvernig námskeiðið hefði hjálpað peim að skilja skipulag rannsóknaritgerða og hvernig peir ættu að setja fram hugmyndir sínar. Раð hefði auðveldað peim ritunina pegar henni var stýrt af tilgátu. Oft var vitnað í kafla eða verkefni í bókinni til áréttingar. Annað pema sem nemendur ræddu var munurinn á að skrifa ensku í framhaldsskóla og í háskóla en margir gátu pess að peir hefðu aldrei skilið tilgang tilgátna og ekki 
áttað sig á hvernig skipuleggja ætti textann fyrirfram fyrr en í pessu námskeiði. Petta kemur fram í eftirfarandi dæmi:

While I was in [upper secondary school] I took all the English courses that were available. What I found really frustrating while starting at the University of Iceland was how I did not have any good background in the development and the process of writing a paper ... (Student \#99).

Priðja pemað var svo munurinn á akademískri ritun í ensku og öðrum tungumálum sem margir nemendur vísa til og er óumdeilt. Áberandi var að textar nemenda sem ekki áttuðu sig á mikilvægi tilgátu í enskum textum báru vott um minni færni í ensku (Birna Arnbjörnsdóttir og Patricia Prinz, 2017).

Par sem markhópur kennslufræðinnar er nemendur með færni upp á C1 var ljóst að hún hentaði ekki nemendum með minni færni pví hugleiðingar nemenda sem ekki höfðu gott vald á ensku bentu til pess að peir nytu ekki eins góðs af kennslunni og hinir. Er pað mat höfundar að niðurstaðan sýni líka að pað purfi sérsniðna nálgun til að mæta pörfum nemenda eins og flestra peirra íslensku nemenda sem koma í Háskóla Íslands. Hefðbundin kennsla með áherslu á málfræði á ekki við pennan hóp og kennsla með áherslu á akademíska ensku mætir ekki pörfum peirra sem ekki hafa góða færni í málfræðilega réttu máli. Íslenskir nemendur gera ekki margar mál- og málfræðivillur í ensku.

Í framhaldi af pessari rannsókn var sett á fót námsleið í akademískri ensku. Pangað var nemendum sem ekki höfðu ensku upp á C1 beint, fremur en í BA-námskeið. Með pví var hægt að laga kennsluna í ritun í BA-námi að pörfum nemenda með áherslu á ritun sérhæfðra texta í bókmenntum og málvísindum.

\section{Rannsókn á mælanlegum framförum í ritun texta}

Fyrri rannsóknir á pví sem hér er til umfjöllunar byggðust á viðhorfum nemenda til eigin ritfærni. Vorið 2016 var safnað textum nemenda í tveimur könnunum, p.e. í upphafi og við lok sama námskeiðs í ritpjálfun í akademískri ensku. Pað misseri skrifuðu 56 nem- 
endur texta sem voru hluti af könnununum. Nemendur fengu sömu leiðbeiningar í báđum könnunum og sömu nemendur tóku pátt í peim báðum. Umfjöllunarefni ritgerðanna var pó aðeins mismunandi, en fjallaði í báðum tilvikum um afleiðingar niðurhals tónlistar og kvikmynda eða sjónvarpspátta fyrir höfunda. Pess skal getið að vorið 2016 var búið að skipta námsgreininni í BA-nám í enskum bókmenntum og málvísindum annars vegar og akademíska ensku hins vegar. Deir nemendur sem hér um ræðir er sá markhópur sem kennsluaðferðinni er ætlað að mæta, p.e. nemendur í enskum bókmenntum og málvísindum.

Í könnununum voru nemendur beðnir að skrifa stuttar ritgerðir með inngangi (með tilgátu), tveimur efnisgreinum með stuðningi við tilgátuna og niðurlagi. Sérhannaður kvarði var notaður til að meta ákveðna pætti ritunar sem kenndir voru í námskeiðinu og skiptist í: 1. skipulag (e. structure); 2. innihald og samhengi (e. content $\mathcal{E}$ coherence); og 3. málnotkun (e. language). Pessum páttum var svo skipt upp í inngang (e. introduction) með tilgátu (e. thesis); tvær efnisgreinar með inngangssetningum (e. topic sentence) og stuðningssetningum (e. evidence); niðurstöður (e. conclusions); og málfræði og málnotkun. Í málnotkunar- og málfræðihlutanum var sérstaklega metið hvort málið væri formlegt, hvort málfræðivillur væru áberandi og hvort samhengi milli efnisgreina bætti flæði textans. Stigin fyrir hvern pátt voru frá 0-10, skipt niður í 0-2 (óviðunandi), 3-4 (ekki nægjanlegt), 5-7 (viðunandi) og 8-10 (ágætt/mjög gott). Sem dæmi voru gefin 0-2 stig ef samhengi var ekki til staðar eða notuð voru óviðeigandi orð en 8-10 stig fyrir tengiorð sem bættu flæði og auðveldaði skilning á textanum. Hverjum pætti fylgdi svo nákvæm lýsing á viðmiðum innan hvers matsramma. Tveir matsmenn með sérstaka pjálfun í notkun rammans í námskeiðinu mátu hvern texta. Rammann (sem byggður er á hefðbundnum viðmiðum í ritunarmati en unninn af Patriciu Prinz) má sjá hér fyrir neðan: 


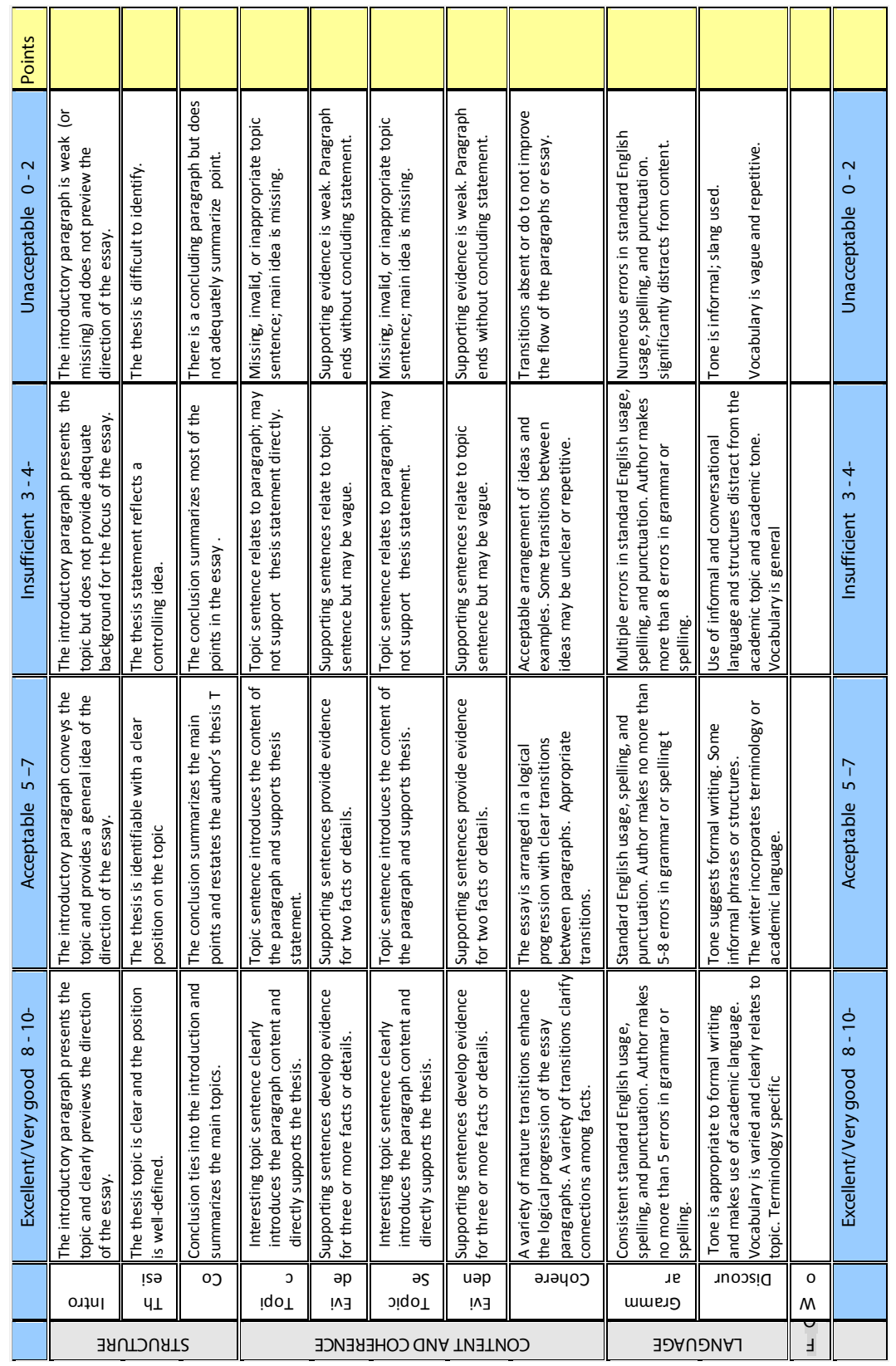




\section{Niðurstöður}

Í töflu 1 má sjá niðurstöður greiningar texta nemenda í upphafi og við lok námskeiðsins. Framfarir voru í öllum páttum ritunar sem greindir voru, fyrir utan málfræðipáttinn, par sem engar breytingar urðu en par eru stigin langhæst sem bendir til bess að nemendur noti málfræðilega rétt mál. Prósentan -1 er innan skekkjumarka.

\begin{tabular}{|l|l|l|l|}
\hline & Könnun í upphafi & Könnun ílok & Mismunur \% \\
\hline Skipulag & & & \\
\hline Inngangur & 5,62 & 6,48 & $15 \%$ \\
\hline Tilgáta & 4,86 & 5,92 & $22 \%$ \\
\hline Lokaorð & 4,78 & 6,26 & $31 \%$ \\
\hline Inngangssetning 1 & 4,86 & 5,7 & $17 \%$ \\
\hline Stuðningur 1 & 4,48 & 5,34 & $19 \%$ \\
\hline Inngangssetning 2 & 4,66 & 5,84 & $25 \%$ \\
\hline Stuðningur & 4,72 & 5,5 & $17 \%$ \\
\hline Málnotkun & & & \\
\hline Tengiorð/fæði & 4,0 & 4,94 & $24 \%$ \\
\hline Málfræði & 7,2 & 7,1 & $-1 \%$ \\
\hline Akademískt mál & 5,86 & 6,36 & $9 \%$ \\
\hline
\end{tabular}

Mestu framfarir urðu í notkun nemenda á tilgátum (22\%) og inngangssetningum (25\%) og pá virtust nemendur átta sig vel á uppbyggingu lokaorða (31\%) og hlutverki tengiorða eða 24\%. Vikið verður að pessum niðurstöðum í umræðukaflanum hér á eftir.

\section{Umræða}

Niðurstöðurnar í pessum könnunum verða að teljast jákvæðar. Öll atriðin sem mæld voru voru tekin fyrir og æfð sérstaklega í námskeiðinu. Pó veldur pað vissum vonbrigðum að nemendur skyldu aðeins bæta sig um 9\% í notkun á formlegu, akademísku máli en slíkum æfingum var pví fjölgað í bókinni og námskeiðinu í kjölfarið. 
Nemendur áttuðu sig hins vegar greinilega á innihaldi lokaorða og inngangsorða en í námskeiðinu er miklum tíma varið í að kenna peim að skrifa inngang og lokaorð sem innihalda pætti sem kennarinn væntir, s.s. tilgátu í inngangi, og að getið sé veikleika rannsóknarinnar, spurninga sem vakna og að nýjar upplýsingar eigi ekki við í lokaorðunum. Niðurstöður sýndu greinilega að um fjórðungur nemenda hafði áttað sig á mikilvægi tilgátna og inngangssetninga sem hjálpa lesandanum að átta sig á framsetningunni. Pá var $24 \%$ aukning nemenda sem áttuðu sig á mikilvægi réttra tengiorða í akademískum texta. Раð аð nemendur skyldu ekki bæta sig í málfræði kemur ekki á óvart par sem sáralítil málfræði var kennd í námskeiðinu en forkannanir höfðu ítrekað sýnt að pess væri ekki pörf. Framfarir voru alls um 16\% ef -1 í málfræði er tekinn með en án málfræðipáttarins voru framfarir um 20\%. Рað skal ítrekað að nemendur skoruðu mjög hátt í málfræði bæði fyrir og eftir námskeiðið. Vissulega er möguleiki á að nemendur hefðu bætt sig í akademískri ritun pótt önnur aðferðafræði hefði verið notuð. Hins vegar er ljóst að nemendur lærðu pað sem fyrir peim var haft í pessu námskeiði með pessari nálgun. Í forkönnunni kom skýrt fram að nemendur pekktu almenn hugtök úr fyrra námi í ensku en gátu ekki beitt peim í ritun. Eftir petta námskeið áttuðu margir nemenda sig á pýðingu hugtaka í ritun og ritgerðir peirra báru pess merki.

\section{Lokaorð}

Kennarar og fræðimenn eru sammála um að taka beri tillit til færni og parfa nemenda pegar enskukennsla er skipulögd. Nýr hópur háskólanema sem sækir nám í eigin landi parf æoftar að lesa námsbækur og fræðigreinar á ensku en einnig að skrifa ritgerðir og preyta próf á pví máli. Peir fá pó ekki enskukennslu í háskólanum en purfa að reiða sig á enskufærni úr framhaldsskóla par sem markmiðið í námskrá í ensku er einfaldlega annað og almennara en að pjálfa nemendur fyrir næsta skólastig. En pegar pjóðskólar krefjast akademískrar færni í öđru tungumáli en pví sem nemendur hafa áđur fengið sína menntun í parf annaðhvort að breyta áherslum á fyrri skólastigum eða veita nemendum pá aðstoð í akademískri ensku sem peir purfa til 
að geta tileinkað sér námsefnið í pví námi sem peir stunda. Nálgunin sem hér hefur verið lýst er ein af peim fyrstu par sem reynt er markvisst að mæta pörfum pessa hóps háskólanema. Rannsóknir á árangri nálgunarinnar sýna að hún bætir skilning nemenda á peim páttum sem einkenna uppbyggingu akademískra texta á ensku. Petta á bæði við um upplifun nemendanna sjálfra og mælingar á framförum í textagerð við upphaf og lok kennslu. Rannsóknirnar sem hér hefur verið lýst hafa ákveðnar takmarkanir, m.a. pær að nemendurnir stunda nám í enskum bókmenntum og málvísindum, og pví erfitt að alhæfa um niðurstöður. Рað verður gert í sîðari rannsóknum en næsta skref í rannsóknum okkar er að kanna hvort pessar framfarir í skilningi á uppbyggingu texta í ritun yfirfærist á lestur.

Háskóli sem leitast við að efla alpjóðlega ásýnd sína með pví að fjölga námskeiðum og námsleiðum sem kenndar eru á ensku parf jafnframt að beina athygli að pörfum nemenda sem stunda slíkt nám. Námið sem hér hefur verið kynnt er viðleitni til pess að styðja við pennan vaxandi hóp nemenda. Í nálguninni er leitast við að auka skilning nemenda á eðli akademísks máls á ensku, leiða pá til sjálfstæðis í vinnubrögðum og hjálpa peim að átta sig á væntingum sem gerðar eru til uppbyggingar texta innan hvers fræðasviðs. Unnið er að pessum markmiðum með pví að pjálfa nemendur í að vinna með pá pætti ritunar sem eru undirstaða texta sem eru algengastir í háskólanámi, p.e. esseyjur, tilviksskýrslur og rannsóknarritgerðir. Par sem kennsla í ritun í hverri fræðigrein fyrir sig er kostnaðarsöm mætti byrja, eins og gert er með pessari nálgun, á grunnpáttum ritunar á háskólastigi og hjálpa nemendum til sjálfstæðis við að kynna sér ritun í sínum námsgreinum. Líkt og listamaður sem verður að ná góðum tökum á grunnpáttum teikningar áđur en hann getur próað persónulegan stíl parf sá sem skrifar að tileinka sér grunnpætti ritunar áđur en hann próar eigin stíl. Petta á við um alla textagerð. 


\section{Enska sem kennslumál við Háskóla Íslands og kennsla í akademískri ensku}

Á sama tíma og kennsla á ensku fer vaxandi við norræna háskóla hefur athygli verið vakin á peim vandkvæðum sem fylgja pví að nemendum og kennurum sé gert að læra og kenna á sérhæfðu, erlendu tungumáli sem peim er ekki vel tamt. Í nýlegri skýrslu sem gefin var út af British Council kemur fram að merkja megi pessa próun um allan heim. Ísland hefur ekki farið varhluta af breytingunum en lokaritgerðum sem ritaðar eru á ensku fer fjölgandi í íslenskum háskólum og sífellt fleiri námskeið á háskólastigi eru kennd á ensku. Í pessari grein er lýst viðbrögðum námsbrautar í ensku við breyttu málumhverfi í Háskóla Íslands en sífellt fleiri nemendur purfa nú að læra á ensku án nægilegrar færni í málinu. Margir peirra brugðu áđur á pað ráð að skrá sig í námskeið í enskum bókmenntum og málvísindum í von um að bæta almenna enskufærni sína. Petta leiddi til pess að námskeiðin urðu of fjölmenn og erfitt reyndist að mæta mismunandi pörfum og markmiðum nemenda. Kennaraskipti urðu einnig tî̉ og framfarir nemenda ófullnægjandi, sérstaklega í ritun. Til að bregðast við pessu var sett á fót ný námsleið í akademískri ensku og námskeiðum í enskri ritun gerbreytt. Úr varð ný nálgun sem lýst er 1 bókinni The Art and Architecture of Academic Writing. Í greininni er nálguninni lýst og sî̉an kynntar niðurstöður rannsókna á áhrifum hennar á nám nemenda. Par kemur fram að nemendur töldu sig almennt verða betri í enskri ritun, átta sig betur á uppbyggingu texta sem stýrt er af tilgátu og hafa betri skilning á uppbyggingu akademískra texta. Pá er í greininni kynnt ný rannsókn á mælanlegum breytingum milli texta sömu nemenda í upphafi og við lok námskeiðsins en hún sýnir að framfarir urðu ekki eingöngu í hugum nemenda heldur mældust pær líka í textum sem peir skrifuðu við upphaf og lok námskeiðs.

Lykilorð: enska sem kennslumál á háskólastigi, kennsla í akademískri ritun, mismunandi textagerðir og ritunarkennsla 


\section{English as a Medium of Instruction at the University of Iceland and the Role of Academic English Instruction}

At the same time as English as a medium of instruction (EMI) programs proliferate at Nordic universities, studies are beginning to appear that call attention to the challenges faced by teachers and students who teach and learn in their second language in such programs. A recent survey by the British Council found that this is a world-wide trend. Studies in Iceland show that more and more courses are taught in English and the number of final thesis and dissertations written in English at the University of Iceland have increased. This article describes the response by the Department of English to the changing linguistic environment of the University where over $90 \%$ of textbooks are written in English, posing challenges to Icelandic students at their national university. Many students from other departments were signing up for courses in English literature and linguistics hoping to improve their general academic English proficiency. This led to over enrollment in courses and difficulty in meeting diverse student groups' needs. Instructor turnover was frequent and a general dissatisfaction among students and instructors. In an effort to meet students' needs better, a new program in academic English was established and the writing program for BA students was reformed with a writing-to-read approach that targets students in EMI programs specifically. The new approach is presented in the textbook The Art and Architecture of Academic Writing. This article describes the new approach and ongoing research to evaluate whether, and if so, how, the new approach enhances students' writing skills. In previous studies students reported that their writing had improved and that they understood the structure of thesis-driven academic texts as a result of the book and course. Finally, a new study is presented that measured improvements in students' writing samples before and after. The new 
study demonstrates that not only has the course led to students' perceptions of improvement, but that their perceptions are supported by actual improvements in students' writing.

Keywords: English as a medium of instruction in higher education, academic writing instruction, genre-based writing instruction 


\section{HEIMILDIR}

Birna Arnbjörnsdóttir. Enska í háskólanámi. Milli mála 2 (2010), 77-94.

Birna Arnbjörnsdóttir og Gerður Guðmundsdóttir. (2014). Undirbúningur framhaldsskólanemenda fyrir notkun ensku í háskólanámi: Námskrár og nýtt íslenskt málumhverfi. Í Netlu, veftímariti um uppeldi og menntun. Menntavísindasvið Háskóla Íslands. Sótt 3. júlí 2020 af: https://ojs.hi.is/netla/ article/view/1945/958

Birna Arnbjörnsdóttir og Hafdís Ingvarsdóttir (ritstjórar). (2018). Language development across the life span: The impact of English on education and work in Iceland. Springer.

Birna Arnbjörnsdóttir og Hafdís Ingvarsdóttir. (2015). Simultaneous parallel code use: Using English in university studies in Iceland. Í Transcultural interaction and linguistic diversity in higher education: The student experience, A. H. Fabricius og B. Preisler (ritstjórar) (bls. 142-160). Palgrave.

Birna Arnbjörnsdóttir og Patricia Prinz. (2017). From EFL to EMI: Developing writing skills for the humanities. ESP Today 5(2), 5-23.

Dearden, J. (2015). English as a medium of instruction: A growing global phenomenon. British Council. Sótt 11. nóvember 2017 af: https://www.britishcouncil.org/ education/ihe/knowledge-centre/english-language-higher-education/reportenglish-medium-instruction

Doolan, S. M. (2017). Comparing patterns of error in generation 1.5, L1, and L2 first-year composition writing. Journal of Second Language Writing, 35, 1-17.

Dimova, S., Hultgren, A. K. og Jensen, C. (2015). English-medium instruction in European higher education: English in Europe, 3. DeGruyter.

Gardner, S. og Nesi, H. (2013). A classification of genre families in university student writing. Applied Linguistics, 34(1), 25-52.

Guðmundur Edgarsson. (2018). Academic vocabulary proficiency and reading comprehension among Icelandic secondary school students. Í Language development across the life span: The impact of English on education and work in Iceland. Birna Arnbjörnsdóttir og Hafdís Ingvarsdóttir (ritstjórar) (bls. 95-112). Springer.

Hafdís Ingvarsdóttir og Birna Arnbjörnsdóttir. (2013). ELF and academic writing: A perspective from the expanding circle. Journal of English as a Lingua Franca, 2(1), 123-145.

Hall, H., Magee, C. og Clapp, T. (2016). 4-Step model to approach case-base learning in the classroom. MPAEA Journal of Adult Education, 45(2), 24-27.

Hellekjær, G. O. (2009). Academic English reading proficiency at the university level: A Norwegian case study. Reading in a Foreign Language, 21(2), 198-222.

Hellekjær, G. O. (2005). The acid test: Does upper secondary EFL instruction effectively prepare Norwegian students for the reading of English textbooks at colleges and universities? Ó́tgefin doktorsritgerð við Óslóarháskóla.

Holec, H. (1981). Autonomy and foreign language learning. Pergamon Press.

Hultgren, A. K., Gregersen, F. og Thøgersen, J. (2014). English in Nordic universities: Ideologies and practices. John Benjamins. 
Hyland, K. (2017). English in the discipline: Arguments for specificity. ESP Today, 1, 5-23.

Jeeves, A. (2013). Relevance and the L2 self in the context of Icelandic secondary school learners: Learner views. Doktorsritgerð. Háskóli Íslands.

Lave, J. og Wenger, E. (1991). Situated learning: Legitimate peripheral participation. Cambridge University Press.

Lavelle, E. og Zuercher, N. (2001). The writing approaches of university students. Higher Education, 42(3), 373-391.

Malmström, H., Mežek, Š., Pecorari, D., Shaw, P. og Irvine, A. (2016). Engaging with terminology in the parallel-language classroom: Teachers' practices for bridging the gap between L1 and English. ASLA-Symposium, 2016.

Paulsrud, B. Y. (2014). English medium instruction in Sweden: Perspectives and practices in two upper secondary schools. Stockholm University.

Pecorari, D., Shaw, P., Irvine, A. og Malmström, H. (2011). English textbooks in parallel language tertiary education. TESOL Quarterly, 45, 313-333.

Prinz, P. og Birna Arnbjörnsdóttir. (2020). The art and architecture of academic writing. John Benjamins.

Swales, J. M. (2004). Research genres: Exploration and applications. Cambridge University Press.

Wächter, B. og Maiworm, F. (2015). English-taught programmes in European higher education: The state of play in 2014. ACA papers on international cooperation in education. Lemmens Medien GmbH. Sótt 23. maí 2017 af: http:// www.acasecretariat.be/fileadmin/aca_docs/images/members/ACA2015_ English_Taught.pdf

Zimmerman, B. J. (2013). From cognitive modeling to self-regulation: A social cognitive career path. Educational Psychologist, 48(3), 135-147. doi:10.1080/0 0461520.2013 .794676

Zimmerman, B. (1989). A social cognitive view of self-regulated academic learning. Journal of Educational Psychology, 82(3), 1-23. 